\title{
Proposal of Minimal Standards for Describing New Species of the Family Campylobacteraceae $\dagger$
}

\author{
JAN B. URSING,${ }^{1 *}$ HERMY LIOR, ${ }^{2}$ AND ROBERT J. OWEN ${ }^{3}$ \\ Department of Medical Microbiology, University of Lund, Malmö General Hospital, S-21401, Malmö, Sweden ${ }^{1}$; \\ Laboratory Centre for Disease Control, Ottawa K1A OLS, Canada ; and National Collection of \\ Type Cultures, Central Public Health Laboratory, London NW9 5HT, England ${ }^{3}$
}

\begin{abstract}
The International Committee on Systematic Bacteriology Subcommittee on the Taxonomy of Campylobacter and Related Bacteria has agreed in principle on minimum requirements for the description of new species of the family Campylobacteraceae. These requirements, as well as methods for determining specific characteristics, are proposed as minimal standards for the description of new species. In addition to specified phenotypic characteristics, molecular data are required. The placement of a new species should be consistent with the current view on classification usually based on methods such as nucleic acid sequencing, hybridization, or protein fingerprinting.
\end{abstract}

Members of the family Campylobacteraceae are curved or spiral bacteria mainly encountered as commensals or parasites in humans and other warm-blooded animals. The genus Campylobacter was created in 1963 (27), and as a consequence of the taxonomic revisions proposed by Vandamme et al. (37), the emended genus now contains (March 1993) 13 species and four subspecies. The genus Arcobacter was suggested for the former species Campylobacter cryaerophilus and Campylobacter nitrofigilis (37); recently, two additional species, Arcobacter butzleri (12) and Arcobacter skirrowii (38), have been described. The inclusion of the genera Campylobacter and Arcobacter in a separate family, Campylobacteraceae, was suggested by Vandamme et al. (36). Helicobacter pylori, Helicobacter mustelae, Helicobacter cinaedi, and Helicobacter fennelliae, which were originally described as campylobacters $(7,37)$, will not be considered here.

General features of Campylobacteraceae. Curved or occasionally straight rods, 0.2 to $0.9 \mu \mathrm{m}$ wide and 0.5 to $5 \mu \mathrm{m}$ long. The rods may appear as spiral, S-, V-, or comma-shaped forms and may also occur in short or occasionally long chains. Cells may become spherical or coccoid, especially in old cultures. Nonspore-forming. Gram negative. Motile by means of single or occasionally multiple unsheathed flagella at one or both ends. Optimum temperatures of growth range from 30 to $42^{\circ} \mathrm{C}$. They are usually microaerophilic and have a respiratory type of metabolism. Some species may be aerotolerant. Oxidase producing. Carbohydrates are neither fermented nor oxidized. Respiratory quinones are menaquinones. The $\mathrm{G}+\mathrm{C}$ content of the DNA ranges from 28 to $46 \mathrm{~mol} \%$. The type genus is Campylobacter; at present, the only other genus is Arcobacter. The following key features of the genus Arcobacter can be used to distinguish species from those of the genus Campylobacter: growth at $15^{\circ} \mathrm{C}$ but not at $42^{\circ} \mathrm{C}$, aerobic growth at $30^{\circ} \mathrm{C}, \mathrm{G}+\mathrm{C}$ contents of 27 to $30 \mathrm{~mol} \%$, and methyl-substituted menaquinone-6 not present as a major isoprenoid quinone $(36,37)$. Detailed morphological, physiological, and biochemical test results for the various species have been reported previously $(8,22,25,26,29)$ (see also the references given in Table 1).

General comments. The description of a new species or

* Corresponding author.

$\dagger$ Proposal by the International Committee on Systematic Bacteriology Subcommittee on the Taxonomy of Campylobacter and Related Bacteria. subspecies of Campylobacter or Arcobacter should be based on characteristics necessary for assigning the new taxon to the genus and on characteristics serving to differentiate the new taxon from existing taxa of the genus. The description should be based on as many strains as possible, preferably not fewer than 10. For critical comparisons with other species, controls consisting of type or reference strains of other species should be tested. For all test procedures, the inoculum size, composition of the gaseous atmosphere, and composition and $\mathrm{pH}$ of the medium should be stated. When possible, standardized, well-described tests and methods should be followed $(1,15,16$, 23, 24, 29).

Cell morphology. The shape, size, and spiral wavelength (where appropriate) of bacteria should be reported. The tendency to undergo rapid transformation to coccoid forms on exposure to air should also be indicated. Indicate whether stained preparations or wet mounts are used for microscopic observations. The number and arrangement of flagella should preferably be determined by electron microscopy; in which case, the presence or absence of flagellar sheaths should be reported.

Staining behavior. The behavior of the cells in the Gram stain must be stated.

Motility. Active, darting motility should be observed by microscopic examination of wet mounts or hanging drop preparations of young cultures in buffered saline or broth.

Colony morphology. The shape, size, and color of colonies should be described. The presence of swarming on solid media should be noted.

Growth conditions. Factors affecting growth should be tested under conditions that are near optimal unless stated otherwise.

(i) Culture medium. Growth on unsupplemented nutrient agar should be tested. When using blood-supplemented nutrient agar, the type and the percentage of blood used should be reported as well as any hemolytic activity observed.

(ii) Temperature range. The ability to grow in specified broth or agar media from standardized inocula at various temperatures should be reported with the time of incubation. The following temperatures should be used: $15,25,36$, or $37^{\circ} \mathrm{C}$ and 42 or $43^{\circ} \mathrm{C}$ (preferably the latter).

(iii) Gaseous requirements. The ability of the strains to grow under aerobic conditions and under microaerobic conditions should be reported; the oxygen content should be specified in the latter instance and if formate or hydrogen is needed. 
TABLE 1. Species, subspecies, and biovars of Campylobacteraceae

\begin{tabular}{|c|c|c|c|}
\hline \multirow{2}{*}{ Name } & \multirow{2}{*}{ Reference(s) } & \multicolumn{2}{|c|}{ Type strain designation } \\
\hline & & Original & Culture collection $^{a}$ \\
\hline Arcobacter butzleri & 12,38 & D2686 & ATCC 49616 \\
\hline Arcobacter cryaerophilus & 37 & A169/B & NCTC 11885 \\
\hline Arcobacter nitrofigilis & 37 & $\mathrm{C} 1$ & ATCC 33309 \\
\hline Arcobacter skirrowii & 38 & $449 / 80$ & CCUG 10474 \\
\hline Campylobacter coli ${ }^{\mathrm{AL} b}$ & 39 & 1407 & CIP 7080 \\
\hline Campylobacter concisus & 33 & FDC 484 & ATCC 33237 \\
\hline Campylobacter curvus (previously Wolinella curva) & 34,37 & VPI 9584 & NCTC 11649 \\
\hline Campylobacter fetus subsp. fetus ${ }^{\mathrm{AL}}$ & 39 & Mouton 1 & CIP 5396 \\
\hline Campylobacter fetus subsp. venerealis ${ }^{\mathrm{AL}}$ & 39 & $\mathrm{X} / 161 / 5$ & CIP 6829 \\
\hline Campylobacter helveticus & 31 & D5248 & NCTC 12470 \\
\hline Campylobacter hyointestinalis & 6 & $80-457-7-4$ & ATCC 35217 \\
\hline Campylobacter jejuni $^{\mathrm{AL}}$ subsp. jejuni & 39 & Uccle $91 \mathrm{FB}$ & CIP 702 \\
\hline Campylobacter jejuni subsp. doylei & 32 & 093 & NCTC 11951 \\
\hline Campylobacter lari & 2,40 & WRI $3034 / 77$ & NCTC 11352 \\
\hline Campylobacter mucosalis & 24 & FS $253 / 72$ & NCTC 11000 \\
\hline Campylobacter rectus (previously Wolinella recta) & 33,37 & FDC 371 & NCTC 11489 \\
\hline Campylobacter showae & 5 & SW A4 & ATCC 51146 \\
\hline Campylobacter sputorum biovar sputorum ${ }^{\mathrm{AL}}$ & 25 & S-17 & ATCC 35980 \\
\hline Campylobacter sputorum biovar bubulus ${ }^{\mathrm{AL}}$ & 25 & Wat & CIP 53103 \\
\hline Campylobacter sputorum biovar fecalis & 25 & C-32 & NCTC 11415 \\
\hline Campylobacter upsaliensis & 26 & $\mathrm{C} 231$ & NCTC 11541 \\
\hline
\end{tabular}

${ }^{a}$ Collections in which the strains were apparently first deposited. ATCC, American Type Culture Collection, Rockville, Md.; CIP, Collection Bactérienne de l'Institut Pasteur, Paris, France; NCTC, National Collection of Type Cultures, London, England; CCUG, Culture Collection of the University of Göteborg, Göteborg, Sweden.

${ }^{b} \mathrm{AL}$ indicates that the species is on the Approved Lists of Bacterial Names $(17,28)$.

Anaerobic growth should be tested, and the requirement for fumarate alone, hydrogen and fumarate, or fumarate and formate should be investigated if considered appropriate $(25$, $30)$.

Biochemical properties. The tests for the following are required: (i) oxidase activity, by using any conventional method such as that described by Kovács (14); (ii) catalase activity, with percentage of reagent solution and time of observation given; (iii) acid production from glucose by oxidation and fermentation by the method of Hugh and Leifson (10); (iv) nitrate reduction in a broth or a semisolid medium or by the method of Cook (4); (v) indoxyl acetate hydrolysis, preferably by the disc method (21); (vi) $\mathrm{H}_{2} \mathrm{~S}$ production from a medium containing sodium thiosulfate, preferably as triple sugar iron (TSI) agar or sulfide-indole-motility (SIM) medium (of these two media, it has been shown that TSI agar is the more sensitive [22]); (vii) urea hydrolysis by the rapid test for preformed enzyme on Christensen's agar or in broth (19); and (viii) sodium hippurate hydrolysis by the rapid test of Hwang and Ederer (11) or an appropriate modification (9) (it is recommended that negative or equivocal results are confirmed by chromatographic assay for benzoic acid [13]).

Other tests. Tests for the following are desirable: (i) tolerance to 1.5 and $3.5 \% \mathrm{NaCl}$ in brucella albimi broth or agar medium, (ii) anaerobic growth in the presence of $0.1 \%$ (wt/vol) trimethylamine $N$-oxide hydrochloride (TMAO) (2), (iii) rapid $\mathrm{H}_{2} \mathrm{~S}$ production in iron-bisulfite-pyruvate (FBP) agar $(1,29)$, (iv) growth in the presence of triphenyltetrazolium chloride $(0.04 \%)(2)$, and (v) tolerance to $1 \%$ glycine in brucella albimi broth medium.

Resistance to antimicrobial agents. Susceptibility to nalidixic acid $(30 \mu \mathrm{g})$ and cephalothin $(30 \mu \mathrm{g})$ should be determined by diffusion tests with Mueller-Hinton agar. The absence of a clear zone of inhibition should be recorded as resistance; for susceptible strains, the zone sizes should be stated.
Molecular data. Standard methods for the determination of the guanine-plus-cytosine content of DNA (melting temperature or chemical) may be used (20). Reference DNA preferably of Escherichia coli NCTC 9001 (G+C, $51 \mathrm{~mol} \%$ ) should be analyzed at the same time. The strain used and its estimated $\mathrm{G}+\mathrm{C}$ content (moles percent) expressed relative to the reference DNA should be reported.

Determination of major cellular fatty acids and respiratory quinone content is strongly recommended $(3,41)$, particularly for the presence of methyl-substituted menaquinone- 6 .

The suggested new species and its nearest neighbors should be investigated by a method giving a broader view of genotypic relationships. Thus, relationships to other species of Campylobacteraceae should be determined by DNA-DNA hybridization (20), and percentage of relatedness to the type strains of the other species should be stated. It should be noted that computer-assisted analysis of one-dimensional electrophoretic protein patterns provides taxonomic discrimination comparable to that of DNA-DNA hybridization (18) and could be considered a possible alternative. If the new species is not significantly related by DNA-DNA hybridization to any species of Campylobacteraceae, its relation to the two genera of the family and to other allied genera, particularly Helicobacter and Wolinella, should be established by $16 \mathrm{~S}$ rRNA sequence similarities (35) or by rRNA-DNA hybridization and thermal stability studies (37).

Ecology. The natural habitat(s) of the proposed species should be detailed as much as possible, and its pathogenicity and host range, if known, should be reported.

We thank the following other (past and present) members of the ICSB Subcommittee on the Taxonomy of Campylobacter and Related Bacteria for their helpful comments and discussions: J.-P. Butzler (Belgium), J. H. Bryner (United States), J. G. Fox (United States), M. A. Karmali (Canada), G. Lawson (United Kingdom), F. Mégraud (France), G. K. Morris (United States), C. M. Patton (United States), 
J. L. Penner (Canada), R. Sakazaki (Japan), and K. Wachsmuth (United States). We are also indebted to M. M. Garcia, S. C. Goodwin, S. D. Neill, and M. Skirrow for further helpful comments and suggestions.

\section{REFERENCES}

1. Barrett, T. J., C. M. Patton, and G. K. Morris. 1988. Differentiation of Campylobacter species using phenotypic characterization. Lab. Med. 19:94-102.

2. Benjamin, J., S. Leaper, R. J. Owen, and M. B. Skirrow. 1983. Description of Campylobacter laridis, a new species comprising the nalidixic acid resistant thermophilic Campylobacter (NARTC) group. Curr. Microbiol. 8:231-238.

3. Collins, M. D., M. Costas, and R. J. Owen. 1984. Isoprenoid quinone composition of representatives of the genus Campylobacter. Arch. Microbiol. 137:168-170.

4. Cook, G. T. 1950. A plate test for nitrate reduction. J. Clin. Pathol. 5:359.

5. Etoh, Y., F. E. Dewhirst, B. J. Paster, A. Yamamoto, and N. Goto. 1993. Campylobacter showae sp. nov., isolated from the human oral cavity. Int. J. Syst. Bacteriol. 43:631-639.

6. Gebhart, C. J., P. Edmonds, G. E. Ward, H. J. Kurtz, and D. J. Brenner. 1985. "Campylobacter hyointestinalis" sp. nov.: a new species of Campylobacter found in the intestines of pigs and other animals. J. Clin. Microbiol. 21:715-720.

7. Goodwin, C. S., J. A. Armstrong, T. Chilves, M. Peters, M. D. Collins, L. Sly, W. McConnell, and W. E. S. Harper. 1989. Transfer of Campylobacter pylori and Campylobacter mustelae to Helicobacter gen. nov. as Helicobacter pylori comb. nov. and Helicobacter mustelae comb. nov., respectively. Int. J. Syst. Bacteriol. 39:397-405.

8. Goossens, H., B. Pot, L. Vlaes, C. Van den Borre, R. Van den Abbeele, C. Van Naelten, J. Levy, H. Cogniau, P. Marbehant, J. Verhoef, K. Kersters, J.-P. Butzler, and P. Vandamme. 1990. Characterization and description of "Campylobacter upsaliensis" isolated from human feces. J. Clin. Microbiol. 28:1039-1046.

9. Harvey, S. M. 1980. Hippurate hydrolysis by Campylobacter fetus. J. Clin. Microbiol. 11:435-437.

10. Hugh, R., and E. Leifson. 1953. The taxonomic significance of fermentation versus oxidative metabolism of carbohydrates by various gram-negative bacteria. J. Bacteriol. 66:24-26.

11. Hwang, M., and G. M. Ederer. 1975. Rapid hippurate hydrolysis method for presumptive identification of group B streptococci. J. Clin. Microbiol. 1:114-115.

12. Kiehlbauch, J. A., D. J. Brenner, M. A. Nicholson, C. N. Baker, C. M. Patton, A. G. Steigerwalt, and I. K. Wachsmuth. 1991. Campylobacter butzleri $\mathrm{sp}$. nov. isolated from humans and animals with diarrheal illness. J. Clin. Microbiol. 29:376-385.

13. Kodaka, S., G. L. Lombard, and V. R. Dowell, Jr. 1982. Gas-liquid chromatography technique for detection of hippurate hydrolysis and conversion of fumarate to succinate by microorganisms. J. Clin. Microbiol. 16:962-964.

14. Kovács, N. 1956. Identification of Pseudomonas pyocyanea by the oxidase reaction. Nature (London) 178:703.

15. Lior, H. 1984. New extended biotyping scheme for Campylobacter jejuni, Campylobacter coli, and "Campylobacter laridis." J. Clin. Microbiol. 20:585-587.

16. Lior, H., and A. Patel. 1987. Improved toluidine blue-DNA agar for detection of DNA hydrolysis by campylobacters. J. Clin. Microbiol. 25:2030-2031.

17. Moore, W. E. C., E. P. Cato, and L. V. H. Moore. 1985. Index of the bacterial and yeast nomenclatural changes published in the International Journal of Systematic Bacteriology since the 1980 approved lists of bacterial names (1 January 1980 to 1 January 1985). Int. J. Syst. Bacteriol. 35:382-407.

18. Owen, R. J., and P. Jackman. 1982. The similarities between Pseudomonas paucimobilis and allied bacteria derived from analysis of deoxyribonucleic acids and electrophoretic protein patterns. J. Gen. Microbiol. 128:2945-2954.

19. Owen, R. J., S. Martin, and P. Borman. 1985. Rapid urea hydrolysis by gastric campylobacters. Lancet i:111.

20. Owen, R. J., and D. Pitcher. 1985. Current methods for estimating
DNA base composition and levels of DNA-DNA hybridization, $p$. 67-93. In M. Goodfellow and D. E. Minnikin (ed.), Chemical methods in bacterial systematics. Academic Press, London.

21. Popovic-Uroic, T., C. M. Patton, M. A. Nicholson, and J. A. Kiehlbauch. 1990. Evaluation of the indoxyl acetate hydrolysis test for rapid differentiation of Campylobacter, Helicobacter, and Wolinella species. J. Clin. Microbiol. 28:2335-2339.

22. Roop, R. M., II, R. M. Smibert, J. L. Johnson, and N. R. Krieg. 1984. Differential characteristics of catalase-positive campylobacters correlated with DNA homology groups. Can. J. Microbiol. 30:938-951.

23. Roop, R. M., II, R. M. Smibert, J. L. Johnson, and N. R. Krieg. 1984. Improved biotyping schemes for Campylobacter jejuni and Campylobacter coli. J. Clin. Microbiol. 20:990-992.

24. Roop, R. M., II, R. M. Smibert, J. L. Johnson, and N. R. Krieg. 1985. Campylobacter mucosalis (Lawson, Leaver, Pettigrew, and Rowland 1981) comb. nov.: emended description. Int. J. Syst. Bacteriol. 35:189-192.

25. Roop, R. M., II, R. M. Smibert, J. L. Johnson, and N. R. Krieg. 1985. DNA homology studies of the catalase-negative campylobacters and "Campylobacter fecalis," an amended description of Campylobacter sputorum, and proposal of the neotype strain of Campylobacter sputorum. Can. J. Microbiol. 31:823-831.

26. Sandstedt, K., and J. Ursing. 1991. Description of Campylobacter upsaliensis sp. nov. previously known as the CNW group. Syst. Appl. Microbiol. 14:39-45.

27. Sebald, M., and M. Véron. 1963. Teneur en bases de l'ADN et classification des vibrions. Ann. Inst. Pasteur (Paris) 105:897-910.

28. Skerman, V. B. D., V. McGowan, and P. H. A. Sneath (ed.). 1980. Approved lists of bacterial names. Int. J. Syst. Bacteriol. 30:225420 .

29. Skirrow, M. 1990. Campylobacter, Helicobacter and other motile curved gram-negative rods, p. 530-549. In M. T. Parker and B. I. Duerden (ed.), Topley \& Wilson's principles of bacteriology, virology and immunity, 8th ed., vol. 2. Systematic bacteriology. Edward Arnold, London.

30. Smibert, R. M. 1984. The genus Campylobacter, Sebald and Véron 1963, 907 ${ }^{\mathrm{AL}}$, p. 111-118. In N. R. Krieg and J. C. Holt (ed.), Bergey's manual of systematic bacteriology, vol. 1. Williams \& Wilkins Co., Baltimore.

31. Stanley, J., A. P. Burrens, D. Lindon, S. L. W. On, M. Costas, and R. J. Owen. 1992. Campylobacter helveticus sp. nov., a new thermophilic species from domestic animals: characterization, and cloning of a species-specific DNA probe. J. Gen. Microbiol. 138:2293-2303.

32. Steele, T. W., and R. J. Owen. 1988. Campylobacter jejuni subsp. doyle $i$ subsp. nov., a subspecies of nitrate-negative campylobacters isolated from human clinical specimens. Int. J. Syst. Bacteriol. 38:316-318.

33. Tanner, A. C. R., S. Badger, C.-H. Lai, M. A. Listgarten, R. A. Visconti, and S. S. Socransky. 1981. Wolinella gen. nov., Wolinella succinogenes (Vibrio succinogenes) Wolin et al. comb. nov., and description of Bacteroides gracilis sp. nov., Wolinella recta sp. nov., Campylobacter concisus sp. nov., and Eikenella corrodens from humans with periodontal disease. Int. J. Syst. Bacteriol. 31:432445 .

34. Tanner, A. C. R., M. A. Listgarten, and J. L. Ebersole. 1984. Wolinella curva sp. nov., "Vibrio succinogenes" of human origin. Int. J. Syst. Bacteriol. 34:275-282.

35. Thompson, L. M., III, R. M. Smibert, J. L. Johnson, and N. R. Krieg. 1988. Phylogenetic study of the genus Campylobacter. Int. J. Syst. Bacteriol. 38:190-200.

36. Vandamme, P., and J. De Ley. 1991. Proposal for a new family, Campylobacteraceae. Int. J. Syst. Bacteriol. 41:451-455.

37. Vandamme, P., E. Falsen, R. Rossau, B. Hoste, P. Segers, R. Tytgat, and J. De Ley. 1990. Revision of Campylobacter, Helicobacter, and Wolinella taxonomy: emendation of generic descriptions and proposal of Arcobacter gen. nov. Int. J. Syst. Bacteriol. 41:88-103.

38. Vandamme, P., M. Vancanneyt, B. Pot, L. Mels, B. Hoste, D. Dewettinck, L. Vlaes, C. Van Den Borre, R. Higgins, J. Hommez, K. Kersters, J.-P. Butzler, and H. Goossens. 1992. Polyphasic taxonomic study of the emended genus Arcobacter 
with Arcobacter butzleri comb. nov. and Arcobacter skirrowii sp. nov., an aerotolerant bacterium isolated from veterinary specimens. Int. J. Syst. Bacteriol. 42:344-356.

39. Véron, M., and R. Chatelain. 1973. Taxonomic study of the genus Campylobacter Sebald and Véron and designation of the neotype strain for the type species Campylobacter fetus (Smith and Taylor) Sebald and Véron. Int. J. Syst. Bacteriol. 23:122-134.
40. von Graevenitz, A. 1990. Revised nomenclature of Campylobacter laridis, Enterobacter intermedium, and "Flavobacterium branchiophila." Int. J. Syst. Bacteriol. 40:211.

41. Wait, R., and M. J. Hudson. 1985. The use of picolinyl esters for the characterization of microbial lipids: application to the unsaturated and cyclopropene fatty acids of Campylobacter species. Lett. Appl. Microbiol. 1:95-99. 